\title{
L2 Teachers' Reasons and Perceptions for Using or Not Using Computer Mediated Communication Tools in Their Classroom
}

\author{
Bahador Sadeghi (Corresponding Author) \\ Department of English, Islamic Azad University, Takestan Branch, PO box 19585-466, Takestan, Iran. \\ Ramin Rahmany \\ Department of English, Islamic Azad University, Takestan Branch, Takestan, Iran \\ Eskandar Doosti \\ Department of English, Islamic Azad University, Takestan Branch, Takestan, Iran
}

\begin{abstract}
This study is an effort to explore Iranian EFL teachers' perceptions about integrating Computer Mediated Communication (CMC) tools in teaching and learning English and reasons they choose or avoid utilizing such tools in the classroom. 100 male and female English teachers with BA, MA, or PhD degree participated in this survey. A questionnaire was used for the purpose of the study. The findings reveal that the majority of teachers were positive towards computer mediated teaching. They asserted that CMC tools are time, energy, and money saving; interesting for the students; reduces cultural barriers by facilitating exposure to the authentic materials; enables teachers to encourage students beyond the limit of time and space; and enables learners to learn at their own pace. The results of the correlational analysis shows that the better teachers were at working with computers the more they showed positive attitudes towards applying technology in their teaching practice.
\end{abstract}

Index Terms - CMC (Computer Mediated Communication), synchronous and asynchronous communication, teacher belief, teacher perception

\section{INTRODUCTION}

The utilization of technology in language learning and teaching has increased rapidly all over the world and teachers today frequently employ and explore new trends to facilitate teaching. Since the introduction of multimedia technology into education many studies that investigated the integration of technology and education and its influence on language teaching and learning have confirmed the advantages of using technology for pedagogical purposes and its positive impact on learning processes in different settings and contexts (Frigaard, 2002; Schofield \& Davidson, 2003; Miner, 2004; Timucin, 2006) and share a common finding related to the effectiveness of technology-enhanced education and its usefulness in developing teaching methods (Wong 2004; Miner, 2004; Brodskaya \& Thiele, 2004; Timucin 2006; Eugene, 2006; Hixon, 2008).

Technology has now equipped language learners with opportunities to learn in ways that was not possible before. New technologies have considerably changed global communication. The technologies have changed how people communicate and also influenced how they learn. The Internet, which transcends international boundaries, allows people to communicate with audiences far away. It also allows users around the globe to join one big learning environment. E-mail, a computer-mediated communication (CMC) technology that relies on the Internet, has become a common and inexpensive way to communicate and learn at a distance. Many scholars have addressed the topics of CMC (Leh, 1999). With the introduction of Computer Mediated Communication (CMC) tools like chat rooms and discussion forums to language learning and teaching, learners find themselves in front of an open door to the real world target language setting and authentic social interaction in which they find the opportunity to have a better command over their own learning experience (Lam \& Lawrence, 2002).

As international communication increases in the movement towards globalization, the demand for communicative competence in English is increasing more and more in many countries of the world including Iran. Teaching English in Iranian schools fails to develop English proficiency for communication. The deficiency of communicative competence in English appears to result from the lack of interpersonal interaction in English as a foreign language (EFL) learning context where English is not used as a means of communication. It is considered very important for L2 teachers to construct an interactive learning environment in which learners can associate with each other in the target language and negotiate meaning through interaction. However, this kind of language interaction rarely appears in the Iranian EFL context. Especially, the classrooms have suffered severely from large sizes and limited opportunities for authentic language interaction, which is said to be necessary for language acquisition. In foreign language situations, it is very 
difficult to have exposure to the target language outside of the classroom. Introducing Computer Mediated Communication (CMC), "communication that takes place between human beings via the instrumentality of computers" (Herring, 1996), into language teaching and learning allows foreign language learners, specifically in an Iranian EFL environment where learners' accessibility to use the target language is very limited, to be greatly exposed to the target language (Blake, 2000; Leh, 1999; Lightbown \& Spada, 1999).

The goal of integrating CMC into language learning is to expose learners to as much language input as possible and motivate them to be more autonomous to the learning. Although language teachers are no longer the center of language classrooms, to maximize the efficiency of CMC in language learning, teachers should carefully consider issues of how to design learning tasks, monitor learners' learning, and evaluate their language progress (Robertson, 2003, as cited in Larsari, 2011). The literature and previous research in this area suggests that CMC equipped teaching can provide language learners with strong motivation, equal participation and an increase of their target language production (Kelm, 1992; Beauvois, 1992; Kern, 1995; Chun, 1998). In addition, it is suggested that synchronous CMC can facilitate the development of socio-linguistic and interactive competence (Kern, 1995; Chun, 1998). However, the foreign language teaching-learning process is an extremely complicated and multifaceted matter. Teachers bring into the classroom their own views of the target language, language tasks, teaching methods and techniques, and the teacher-learner power relationship. Teachers' perceptions play an important role in their actual practices while teaching target language and choosing instructional methods (Staub \& Stern, 2002).

Williams and Burden (1997) argue that teachers are highly influenced by their beliefs. Teachers' beliefs is an extremely complicated phenomenon which involves various aspects, such as beliefs about the nature of language itself, language learning and teaching, learners, teachers, and the teacher-learner power relationship. Such beliefs definitely influence teachers' approaches to EFL teaching and their instructional choices and teaching activities.

\section{A. Statement of the Problem}

Iranian English language classrooms suffer from limited opportunities for authentic language interaction, which is said to be necessary for language acquisition. In foreign language settings that the exposure to the target language is very difficult, CMC can provide the learners with more opportunities to engage in authentic and genuine communication that is characterized by "the uneven distribution of information, the negotiation of meaning through clarification requests and confirmation checks, topic nomination and negotiation by more than one speaker, and the right of interlocutors to decide whether to contribute to an interaction or not" (Nunan, 1987: 137). However, recent studies point to the teacher as the main factor in utilizing technology in classroom amongst the organizational and environmental barriers and factors (Schofield, 1995; Becker \& Ravitz, 2001; Cuban et al., 2001; Windschitl \& Sahl, 2002; Conlon \& Simpson, 2003). Teachers' beliefs and perceptions define their actual practices while teaching target language and employing instructional methods (Staub \& Stern, 2002). Teachers' beliefs and perceptions about using CMC tools and integrating such tools into classroom activities is a deceive factor in their actual practice of computer mediated teaching. Their views about what tools, methods, and techniques can be employed, how significant and necessary are such tools, which is the best tool and method, how much time should be spent on computer mediated activities compared to other types of activities, what are the difficulties of such method, and what activities are more appropriate for computer mediated teaching can improve our understanding of Iranian teachers' perceptions and reasons for using or not using CMC tools in the classroom and help us find out how these beliefs and perceptions affect their Instructional decisions and practices.

\section{B. Objectives of the Study}

This study's aim is to explore Iranian EFL teachers' perceptions about integrating Computer Mediated Communication (CMC) tools in teaching and learning English and reasons they choose or avoid utilizing such tools in the classroom. It will also investigate the teachers' beliefs about computer mediated teaching because as argued by Borg (2003) and Richards, Gallo and Renandya (2001) teacher cognition is shaped by teachers' prior experiences, school practices, educational theory, reading, and individual factors. Individual, organizational, and educational factors can play a role in shaping teachers' beliefs; however, there is not much known about the extent of it.

\section{Research Questions and Hypotheses}

The present study tries to answer the following questions:

RQ1: What are the attitudes and positions of teachers towards computer mediated teaching?

RQ2: For what practical reasons do teachers choose, or avoid, implementing CMC tools?

\section{Significance of the Study}

In the Iranian EFL context, in which learners don't have much contact with native speakers of English, the focus of language teaching has been placed on changing the classroom practice from the traditional passive lecture to more active computer mediated teaching and learning so that learners can be more easily exposed to target language use. Language institutes have had an increasing amount of interest in using computer mediated teaching as an instructional method, chiefly because they believe CMC tools has specific benefits for increasing learners' communication skills, interaction and their exposure to the target language. In this respect, exploring teachers' perceptions of CMC-based 
language instruction is of a great importance. Teaching a foreign language is a demanding task and considerable amount of attention should be paid to the teaching process. Hence, perceptions, beliefs and views of language teachers which greatly influence such process, should be carefully taken into consideration.

This research will show how CMC is perceived to be utilized in education. This will provide insights for syllabus designers to design and implement a more efficient teaching method that increases target language exposure during the limited teaching hours. It will also contribute to assist EFL teachers with their practical use of technology in the classroom. Thus, it is believed that the results of this study will have implications for syllabus and material design and classroom practice. Once curriculum developers and syllabus designers come to know how teachers perceive CMCbased language instruction, they can "if necessary," take into consideration those perceptions and plan alternative materials and activities in their syllabi to make language learning-teaching process a more effective and enjoyable one. Despite the concerns with implementation and the major barriers to use such as maintenance by technical staff, time consuming training and so on today computer technology is a crucial tool in school environment. Since it motivates students and encourages them to explore and to learn in a way previously unavailable to them. Technology may be one means by which doubtful teachers may develop positive beliefs about its role as a tool for learning when it is integrated into the curriculum, rather than merely added to it. Teachers need to believe that they can successfully put into practice the innovation within their own context; They also need to be convinced of the value of technology as a tool to supplement and improve classroom practice. Teachers who believe that they have the skills to implement computers successfully and who valued the outcomes associated with integration were more likely to be at the high end of the "technology user" spectrum.( Wozney, Venkatesh, and Abrami, 2006). Researchers and staff developers have suggested numerous and different factors that may influence the degree to which teachers implement and keep on in the implementation of educational innovations in general. These include personal and demographic factors related to teachers, the quality of professional development offered to teachers, the extent to which administrative and curricular support is available to teachers, as well as the quality of teacher access to computer resources (Wozney, Venkatesh, and Abrami, 2006).

\section{LITERATURE REVIEW}

\section{A. Teachers' Beliefs and Perceptions}

Teachers bring with them beliefs about teaching which effects their use of technology in the classroom. Beliefs about teaching are referred to as "preferred ways of teaching" by teachers. (Teo, Chai, Hung, Lee, 2008). According to Pajares (1992) the difficulty in exploring the teachers' beliefs lies in the multitude of definitions of beliefs .In order to understand, it is important to clearly define and understand what is meant by belief. Despite this diversity there is an agreement on some characteristics of teacher beliefs. Belief is a construct that name, define, and describe the structure and content of mental states that are thought to drive a person's actions (Zheng, 2009). Most of the teachers' professional knowledge can be regarded more accurately as a belief. Beliefs vary in strength and kind; the ease with which teachers can change their beliefs is related to the strength of the particular beliefs under scrutiny (Block \& Hazelip, 1995). Understanding teachers' beliefs requires making inferences based on what teachers say, intend, and do. Indeed, teachers' beliefs represents a complex concept internally associated with their attitudes, expectations and personal experience. Beliefs and attitudes are key factors in whether teachers accept computer as a teaching tool in their teaching practices or not. Teachers who believe that they have the skills to implement computers successfully and who valued the outcomes associated with integration were more likely to be at the high end of the "technology user" spectrum. To maximize the implementation of educational innovations, our findings suggest that professional development must attend to the enhancement of teachers' expectations of success. Teachers need to believe that they can successfully implement the innovation within their own context; if not, they may neither take the initial risk nor continue to persevere in implementing it. This suggests that it may be useful, but not sufficient, to show teachers how successful others have been with technology applications and to create communities of practitioners providing mutual support. Teachers also need to be convinced of the value of technology as a tool to supplement and improve classroom practice. Technology, which is well integrated into the curriculum, rather than merely added to it, may be one means by which skeptical teachers may develop positive beliefs about the role of technology as a tool for learning. (Wozney, Venkatesh, \& Abrami 2006)

\section{B. Computer-mediated Communication (CMC)}

According to Romiszowski and Mason (2004) a working definition of computer-mediated communication is "communication between different parties separated in space and/or time, mediated by interconnected computers." A definition of CMC that, pragmatically and with regards to the rapidly changing nature of communication technologies describes it as "the process by which people create, exchange, and perceive information using networked telecommunications systems that facilitate encoding, transmitting, and decoding messages" (December, 1996). Computer mediated communication (CMC) involves exchanges of information in textual, audio, and/or video formats that are transmitted and controlled by the use of computer and telecommunication technology. (Bubas, 2001). Computer-mediated communication (CMC) is a process in which human data interaction occurs through one or more networked telecommunication systems. A CMC interaction occurs through various types of networking technology and 
software, including email, Internet Relay Chat (IRC), instant messaging (IM), Usenet and mailing list servers.CMC technology saves time and money in IT organizations by facilitating the use of all communication formats.

\section{Advantages of Using CMC}

There are several reasons why technology might be important. These rationales related to social and economic interests, such as reducing the costs of education, supporting the computer industry, preparing students for work and for living in a society permeated with technology, and making the school more attractive to its potential clients.(Zaidiyeen, Mei, and Fook, 2010).

According to Chen (2005) the integration of Computer-Mediated Communication (CMC) into EFL learning can increase both input (exposure) and output (use) of the target language that is needed for learners to promote both their linguistic and pragmatic competence. CMC can facilitate the development of socio-linguistic and interactive competence (Kern, 1995; Chun, 1998). Based on a study done by Drenoyianni and Selwood (1998) a great number of teachers declared that computer use encourages collaborative learning, individualized learning, motivates pupils, and serves as an aid in presenting new concepts, information, problems and situations as well as improving basic skills and concepts. The most important academic goal is developing learning strategies and problem solving abilities which is followed by the goal of developing basic skills and concepts, and developing of social skills. Warschauer (1995) claims that using computer-mediated communication in electronic communication facilitates communication, gives students a sense of achievement, empowers students and enhances learning. According to Razak and Asmawi (2004) the benefits of CMC are: a. Facilitates Communication b. Empowers Students c. Enhances Learning.

The integration of technology in the process of teaching and learning is thought by many researchers to increase student and teacher productivity as well as to make vast amounts of information available. Bena and James (2001) claim that there are three reasons for investing in technology:

1) to increase students ability and interest in applying authentic settings, what district and states have identified as learning and tasks that students should know and able to do.

2) to prepare students for success in a technology centered world of work, and

3) to prepare students to manage and use information so they can be productive life long learners and responsible citizens.

One of the issues of application of CMC is in helping the students acquire academic literacy and gain access to their disciplinary discourse communities via their performance in academic writing tasks (Cheng, 2007). Computer-mediated communication (CMC) allows interactions among geographically separated students, who can communicate and learn through dialogue exchanged on the Internet. Small-group discussion in the classroom can be replaced by transmitting messages via networked computers (Lo, 2009). Computer conferencing and electronic mail lies in their capabilities to support conversation and collaboration. Groups can work together to solve problems, argue about interpretations, negotiate meaning, engage in other educational activities including coaching, modeling, and scaffolding of performance. (Jonassen,et al. 1995). According to Nguyen (2008) motivation, active learning, reflective learning, learner autonomy, and collaborative learning are pedagogical benefits of $\mathrm{CMC}$

\section{Methodology}

\section{A. Design of the Study}

This study is an experimental effort to investigate Iranian language teachers' and learners' perceptions of the utilizations of Computer Mediated Communication tools in classroom. Randomly selected teachers participate in the research and answer the questionnaires. Finally, the data will be collected and analyzed.

\section{B. Participants}

In this study a total of 100 male and female English teachers participated in this survey. Academic qualification of the teachers ranges from $\mathrm{BA}$ to MA to $\mathrm{PhD}$; they are between 22-50 years old, and the number of years they had taught English varies, ranging from less than 2 years, and more than 10 years.

\section{Instruments}

To conduct the present study, the questionnaire will be devised to measure Iranian EFL teachers' perceptions of CMC tools in classroom setting. The questionnaire will be composed of some Likert-scale items and two open-ended items, and it will come in four sections. The first section contains demographic questions in order to gain information about the teacher's academic qualification, gender, age, and teaching experience. The second section is related to teachers' positions on classroom practice of computer mediated teaching. In this section, teachers will be asked to answer each question using a five-point scale ranging from 'strongly disagree' to 'strongly agree'. Finally, in the third section, teachers will be asked to rate their own reasons for choosing or avoiding the implementation of CMC tools, with reference to a few qualitative statements. To ensure the validity of the questionnaires and the appropriateness and comprehensibility of the questionnaire items, some experts in the field will be consulted. Moreover, the reliability coefficients (Cronbach's alpha) of instruments will be estimated. All of the reliability coefficients are expected to be high enough to enable the researchers to conduct statistical analysis of the entire questionnaires. The reliability of the 
questionnaire was tested using Cronbach's alpha. Table 1 shows the result of the reliability test. The Cronbach's alpha of the questionnaire was 0.71 that indicates a relevantly high consistency of the questions, therefore a reliable measure.

TABLE 1.

RELIABILITY STATISTICS OF THE QUESTIONNAIRE

\begin{tabular}{|l|l|}
\hline Cronbach's Alpha & N of Items \\
\hline .710 & 35 \\
\hline
\end{tabular}

\section{Procedures}

In order to carry out the present study, the researcher is going to design a questionnaire to collect data on how language teachers perceive computer mediated teaching. At first, the participants were informed about the purpose of the study. Also, to remove anxiety, it was explained that their answers would not influence their grades. Then, the necessary information about the questionnaires was given. At last, the questionnaires were distributed among the participants in one session

\section{E. Data Analysis}

After distributing the questionnaires among the English language teachers and collecting the required data. The data analysis process consists of two methodologies, Likert-type and open-ended item analysis. For the Likert-type items the answers will be tabulated and the frequency of the answers will be counted. A non-parametric Kruskal-Wallis test will be run to compare the beliefs of teachers with different academic qualifications and computer expertise level. SPSS (Statistical Package for Social Sciences) was used to analyze the data in this part. For the open-ended question the answers will be surveyed and the most repeated patterns will be revealed.

\section{RESUlTS}

In the next part of this chapter the reliability of the questionnaire is tested and the result is reported. Following that, the results of the analysis of the attitudes and positions of teachers towards using computer in their classrooms are presented. The next part shows the analyses of different aspects of teachers' views about computer mediated communication (CMC) and the application of CMC tools in teaching practice. And finally in the last part of this chapter the result of the analyses of comparing the positions and believes of teachers with different academic qualification towards and about computer mediated teaching and CMC performance.

\section{A. Addressing the First Research Question}

Part two of the questionnaire contained twenty items dealing with this question: What are the attitudes and positions of teachers towards computer mediated teaching?

Table 2 indicates the result of the teachers' responses which shows that the majority of the teachers generally agreed with all items that represent positive attitudes towards the use of computers in teaching practice (the mean score for all these items were above 4 that corresponds to 'agree' and 'strongly agree'). This is while those items that discourage the use of computers in classroom and teaching activities elicited disagreement or a neutral position from the participants. However, despite showing interest in applying technology in their classrooms, teachers mostly did not approve a compulsory computer training program.

TABLE 2.

THE RESULTS OF THE TEACHERS’ RESPONSES TO SECTION TWO

\begin{tabular}{|l|l|l|l|}
\hline & N & Sum & Mean \\
\hline 1 & 100 & 454 & 4.54 \\
2 & 100 & 448 & 4.48 \\
3 & 100 & 412 & 4.12 \\
4 & 100 & 483 & 4.83 \\
5 & 100 & 437 & 4.37 \\
6 & 100 & 419 & 4.19 \\
7 & 100 & 443 & 4.43 \\
8 & 100 & 285 & 2.85 \\
9 & 100 & 453 & 4.53 \\
10 & 100 & 274 & 2.74 \\
11 & 100 & 437 & 4.37 \\
12 & 100 & 409 & 4.09 \\
13 & 100 & 433 & 4.33 \\
14 & 100 & 434 & 4.34 \\
15 & 100 & 400 & 4.00 \\
16 & 100 & 440 & 4.40 \\
17 & 100 & 285 & 2.85 \\
18 & 100 & 412 & 4.12 \\
19 & 100 & 313 & 3.13 \\
20 & 100 & 296 & 2.96 \\
\hline
\end{tabular}




\section{B. Addressing the Second Research Question}

In this part I will summarize the responses of the participants in part three of the questionnaire. In part three of the questionnaire the participants were asked about their reasons for using or avoiding CMC tools in their teaching practice. The majority of teachers asserted that applying CMC tools in their teaching practice is time and energy saving and sometimes more economic. They suggest that CMC tools make information transfer and communication easier, especially in listening skill. Another positive aspect of CMC tools in teaching language that was broadly accepted by the teachers was the fun part of these tools. Most teachers believed that CMC tools make language lessons more interesting to the students. In addition, they suggested that using internet in teaching can decrease the cultural issues that language learners may face. Some teachers mentioned that CMC tools enable them to keep connection with students and to motivate them to cooperate more both inside and outside the classroom. They also believed that students feel more secure using asynchronous tools like email and discussion threads through which they have additional processing time for critical thinking. On the other hand, a few teachers argued against applying CMC tools in teaching. They suggested that computers may decrease the amount of teacher-student or student-student interactions in the classroom. They also believed that considering learners' needs may be overlooked in an online language teaching class. Moreover, they proposed the possibility that some students may not have the time or may not like such ways of communication.

\section{Teachers' Belief and Academic Qualification}

To examine the influence of teachers' academic qualification on their perception about computer mediated teaching and computer mediated communication (forth research question) a non-parametric Kruskal-Wallis test was run. The reason for using a non-parametric test was that the distribution of the data population was not normal. Table 3 demonstrates the descriptive results and table 4 shows the results of non-parametric test.

TABLE 3 .

THE DESCRIPTIVE RESUlTS OF BA, MA, AND PHD TEACHERS' RESPONSES

\begin{tabular}{|c|c|c|c|}
\hline & Academic_Degree & $\mathrm{N}$ & Mean Rank \\
\hline \multirow[t]{4}{*}{ SUM } & $\mathrm{BA}$ & 50 & 46.22 \\
\hline & MA & 48 & 52.96 \\
\hline & $\mathrm{PhD}$ & 2 & 98.50 \\
\hline & Total & 100 & \\
\hline
\end{tabular}

TABLE 4.

RESULTS OF KRUSKAL-WALLIS TEST WITH THREE INDEPENDENT GROUPS OF BA, MA, AND PHD

\begin{tabular}{|l|l|}
\hline & SUM \\
\hline Chi-Square & 6.934 \\
df & 2 \\
Asymp. Sig. & .031 \\
\hline
\end{tabular}

As Table 4 reveals, there is a statistically significant difference in teachers' beliefs about computer mediated language teaching and CMC depending on which level of academic qualification they have achieved, $\chi^{2}(2)=6.934, P=$ 0.031 .

To see which pairs of groups differ significantly I performed post-hoc analysis, comparing groups two by two. Table 5 shows the results of the comparison between BA and MA teachers; table 6 demonstrates the results of the comparison between $\mathrm{MA}$ and $\mathrm{PhD}$, and table 7 reports the results of the comparison between $\mathrm{BA}$ and $\mathrm{PhD}$ teachers.

TABLE 5.

RESULTS OF MANN-WHITNEY TEST WITH TWO INDEPENDENT GROUPS OF BA AND MA

\begin{tabular}{|l|l|}
\hline & SUM \\
\hline Mann-Whitney U & 1036.000 \\
$\mathrm{Z}$ & -1.168 \\
Asymp. Sig. (2-tailed) & .243 \\
\hline
\end{tabular}

TABLE 6.

RESULTS OF MANN-WHITNEY TEST WITH TWO INDEPENDENT GROUPS OF MA AND PHD

\begin{tabular}{|l|l|}
\hline & SUM \\
\hline Mann-Whitney U & 2.000 \\
$Z$ & -2.284 \\
Asymp. Sig. (2-tailed) & .022 \\
Exact Sig. [2*(1-tailed Sig.)] & $.007^{\mathrm{a}}$ \\
\hline
\end{tabular}


TABLE 7.

RESULTS OF MANN-WHITNEY TEST WITH TWO INDEPENDENT GROUPS OF BA AND PHD

\begin{tabular}{|l|l|}
\hline & SUM \\
\hline Mann-Whitney U & .000 \\
$Z$ & -2.392 \\
Asymp. Sig. (2-tailed) & 017 \\
Exact Sig. [2*(1-tailed Sig.)] & $.002^{\mathrm{a}}$ \\
\hline
\end{tabular}

The two groups of BA and MA teachers did not differ significantly with $U=1036, Z=-1.168, p=0.243$. Contrary, $\mathrm{MA}$ and $\mathrm{PhD}$ teachers differed significantly in their beliefs and conceptions about computer mediated teaching and CMC $(\mathrm{U}=2.00, \mathrm{Z}=-2.284, \mathrm{p}=0.022)$. Similar to table 6 , table 7 shows that the two groups of $\mathrm{BA}$ and $\mathrm{PhD}$ teachers differed significantly with $U=0.000, Z=-2.392, p=0.017$. All in all, the analyses shows that while there was not a statistically significant difference between the beliefs of teachers with BA and MA degrees, the two groups differed significantly from $\mathrm{PhD}$ teachers.

\section{Teachers' Belief and Computer Expertise}

To examine how the beliefs and perceptions of teachers about computer mediated teaching (part two of the questionnaire) vary because of differences in their level of computer expertise (fifth research question) a non-parametric Kruskal-Wallis test was run similar to the previous part. Table 8 demonstrates the descriptive results and table 9 represents the results of non-parametric test.Table 8 shows that there is a statistically significant difference in teachers' beliefs depending on their level of computer expertise, $\chi^{2}(3)=22.932, P=0.000$. Table 9 reveals that as teachers develop their computer skills, they grow more positive attitudes towards applying computers in teaching English language generally (mean rank (expert) $=67.11>$ mean rank (intermediate $)=52.84>$ mean rank (novice $)=25.47$ ).

TABLE 8

THE DESCRIPTIVE RESULTS OF NOT EXPERIENCED, NOVICE, INTERMEDIATE, AND EXPERT TEACHERS' RESPONSES
\begin{tabular}{|l|l|}
\hline & Sum_Com \\
\hline Chi-Square & 22.932 \\
df & 3 \\
Asymp. Sig. & .000 \\
\hline
\end{tabular}

TABLE 9

RESULTS OF KRUSKAL-WALLIS TEST WITH THE FOUR INDEPENDENT GROUP

\begin{tabular}{|c|c|c|c|}
\hline & Com_Expertise_Level & $\mathrm{N}$ & Mean Rank \\
\hline \multirow[t]{5}{*}{ Sum_Com } & Not Experienced & 5 & 28.00 \\
\hline & Novice & 16 & 25.47 \\
\hline & Intermediate & 56 & 52.84 \\
\hline & Expert & 23 & 67.11 \\
\hline & Total & 100 & \\
\hline
\end{tabular}

\section{DISCUSSION}

The findings confirmed that the majority of Iranian EFL teachers show positive attitudes towards the use of computer in their English classroom and find teaching with the aid of computer effective both for the teachers and learners. In fact, it showed those teachers who were highly skilled with computer were more willing to apply computers in their classrooms. This is in line with Bauer and Kenton (2005) who found that teachers, who were proficient with technology, were innovative in using technology in their teaching and managed to overcome barriers. The findings also confirmed Zhao (2007) who, following a qualitative research to investigate the perspectives and experiences of 17 social studies teachers, concluded that most teachers were willing to use technology and expressed positive experiences with technology integration training. Looking through the perspective of Iranian EFL teachers, the study divided the advantages of applying CMC tools to foreign language teaching into five categories: time, energy, and money saving; interesting for the students; reduces cultural barriers by facilitating exposure to the authentic materials; enables teachers to encourage students beyond the limit of time and space; and enables learners to learn at their own pace. These categories are in line with Blake (2001) and Warschauer \& Healey (1998) who confirmed that integrating technology appropriately into language classrooms provides access to authentic materials thus greater opportunities for communication and interaction and promotes learner motivation.

In the second part of the study where the aspects of teachers' views about computer mediated communication were investigated the results showed that teachers were comfortable communication with familiar persons through CMC tools, they accepted that CMC messages are social forms of communication and have qualities or characteristics but according to them $\mathrm{CMC}$ messages are not informal and casual ways to communicate, something that is not in agreement with Tu's exploratory factor analysis (2002). Again while Tu's (2002) model show that CMC messages convey feeling and emotion, the results of the study shows that the majority of Iranian EFL teachers disagree. These two points of disagreement in the beliefs and perspectives of Iranian EFL teachers seem to a barrier to an optimal application of 
online content as an undeniable source of authentic communication. It is also inconsistent with what most teachers have mentioned in response to the third research question about the contribution of CMC to reducing cultural barriers. These contradictions in the beliefs and perceptions of teachers about computer mediated teaching and computer mediated communication may be due to the fact that these concepts are new in the Iranian teaching environment and there has not been any systematic educational program for teachers. There is a need for an organized program for teachers including the introduction of different CMC tools and computer programs as well as guidelines for successful technology integration in language teaching.

The above points were confirmed when we looked at the analyses results of the effect of academic qualification and computer expertise. It revealed that $\mathrm{PhD}$ teachers and technologically competent teachers showed more positive attitudes towards applying computers in teaching English language.

For what practical reasons do teachers choose, or avoid, implementing CMC tools?

The answers to the third research question concerning the motives behind the use or avoidance of CMC tools by teachers are summarized below:

\begin{tabular}{|l|l|}
\hline Reasons why teachers use CMC tools in teaching & Reasons why teachers avoid using CMC tools in tesching \\
\hline $\begin{array}{l}\text { Time, energy, and money saving (make information transfer and } \\
\text { communication easier) }\end{array}$ & $\begin{array}{l}\text { decrease the amount of teacher-student or student-student } \\
\text { interactions in the classroom }\end{array}$ \\
\hline Interesting and fun for the students & Ignore individual learners' needs \\
\hline Reduces cultural barriers by providing authentic material & $\begin{array}{l}\text { some students may not have the time or may not like such ways } \\
\text { of communication }\end{array}$ \\
\cline { 1 - 1 } $\begin{array}{l}\text { Enable teachers to keep in touch with students and to encourage them } \\
\text { inside and outside the classroom }\end{array}$ & \\
\cline { 1 - 2 } $\begin{array}{l}\text { students feel more secure as they learn language at their own pace and } \\
\text { have as much processing time as they wish }\end{array}$ & \\
\hline
\end{tabular}

\section{CONCLUSION}

In Iranian EFL context, because learners don't have direct contact with native speakers of English, there has been an emphasis on authenticity in language classrooms recently contrary to the traditional lecture for the learners to become more acquainted with the target language in use. As a result, teachers are keener on using computer mediated communication tools, primarily because they believe CMC benefits learners' communication skills and interaction. Online language tasks can be used to arouse learners' motivation for learning a foreign language. These tasks don't just give variety to the language teaching methodology but also make the classroom much more fun and interesting; besides, they can produce a lively atmosphere in the classroom which gives language instruction more creativity.

Generally, the findings of this study manifested the fact that the majority of Iranian EFL teachers have positive attitudes towards computer mediated teaching and using computer mediated communication tools in the classroom however, they did understand CMC concepts and their integration into teaching language deeply. While the results of the questionnaire showed that teachers were unwilling to participate in a computer training program the need for such a program to familiarize the teachers with the newest CMC tools and the optimum way to integrate such tools in teaching different language skills and components was strongly felt.

\section{Implications of the Study}

Concerning the results of the study, some notifying suggestions are given to teachers and teacher trainers. First, because teachers' attitudes towards computer mediated teaching highly influence classroom practice, it is necessary for the teachers to have a positive attitude so that it can be successfully used. Although EFL teachers in Iran are not accustomed to a computer mediated language teaching class in the educational system, it does not mean that one should put it aside and follow traditional methods of language teaching. Second, as the attitudes of Iranian EFL teachers to CMC were rather positive in this study, EFL teachers are encouraged to adopt these tools in their classrooms. In this regard, the managers of private English institutes should also do their best to promote computer mediated teaching at their institutes. This involves providing the required tools and equipments and a systematic training program because some teachers know little about applying computer mediated communication tools. That is why they should be given the chance to educate themselves in fields relating to CMC tools and the putting into teaching practice of these tools. For this purpose, computer training programs should properly deal with the strengths and weaknesses of CMC tools as a language teaching tool. Third, lack of confidence is one of the reasons why teachers avoid computer mediated teaching therefore, it should be given consideration to overcome these impediments in the classroom.

\section{APPENDIXES}

Appendix A
1. Gender
Male $\bigcirc$
Female $\bigcirc$
2. You are
20-25
26-35
$36-45$
3. Estimate of your level of computer expertise. 
No experience $\bigcirc \quad$ Novice $\bigcirc \quad$ Intermediate $\bigcirc \quad$ Expert $\bigcirc$

4. Where do you presently use computer? (Check all that apply)

Home $\bigcirc$ Computer Lab $\bigcirc$ Library or Media Center $\bigcirc$ Classroom $\bigcirc$ Office $\bigcirc$

5. What is your highest degree earned? Bachelor $\bigcirc \quad$ MA $\bigcirc \quad$ Ph.D $\bigcirc$

\section{APPENDIX B}

Attitude toward the Use of Computers for Language Teaching

Please check $(\sqrt{ })$ in the box that best reflects your opinion about each of the following statements using this scale: $\mathrm{SA}=$ Strongly Agree $\quad \mathrm{A}=$ Agree $\quad \mathrm{N}=$ Neutral $\quad \mathrm{D}=$ Disagree $\quad \mathrm{SD}=$ Strongly Disagree

\begin{tabular}{|c|c|c|c|c|c|c|}
\hline No & & SA & A & $\mathrm{N}$ & $\mathrm{D}$ & SD \\
\hline 1 & I like to use computers in teaching. & & & & & \\
\hline 2 & Computers have proved to be effective learning tools. & & & & & \\
\hline 3 & Computers will increase the amount of teacher-student interaction in the classroom. & & & & & \\
\hline 4 & Computers are a fast means of getting information. & & & & & \\
\hline 5 & Computers save time and effort. & & & & & \\
\hline 6 & The use of computers can help improve language learners' communication skills. & & & & & \\
\hline 7 & The use of computers brings more advantages than disadvantages to language teachers. & & & & & \\
\hline 8 & $\begin{array}{l}\text { Using computers in the language classroom will not improve students' attitudes toward language } \\
\text { learning. }\end{array}$ & & & & & \\
\hline 9 & Teaching language with the aid of computers would make learning easier for language learners. & & & & & \\
\hline 10 & Language teaching is better without the use of computers. & & & & & \\
\hline 11 & Computers will increase the amount of student-student interaction in the class. & & & & & \\
\hline 12 & Students" motivation increases as a result of using technology in teaching. & & & & & \\
\hline 13 & Students are more active in computer-aided language lessons. & & & & & \\
\hline 14 & Using a computer makes language lessons more interesting to the students. & & & & & \\
\hline 15 & Computers can be used as a private tutor. & & & & & \\
\hline 16 & Technology plays a great role in learning the different language skills. & & & & & \\
\hline 17 & The use of computers is unrelated to the needs of the school. & & & & & \\
\hline 18 & Teaching language with the aid of computers makes teaching easier. & & & & & \\
\hline 19 & A computer training program should be compulsory for every language teacher. & & & & & \\
\hline 20 & Language teachers can manage without computers, so computers are not really necessary. & & & & & \\
\hline
\end{tabular}

\section{APPENDIX C}

1. How many years have you been using the different forms of Computer-Mediated Communication? Which tools / forms do you prefer to use?

2. What's your main purpose for using or avoiding $\mathrm{cmc}$ tools?

\section{REFERENCES}

[1] Bauer, J., \& Kenton, J. (2005). Toward technology integration in schools: Why it is not happening. Journal of Technology and Teacher Education, 13, 519-546.

[2] Beauvois, M. (2000). Computer assisted classroom discussions in the foreign language classroom: Conversation in slow motion. Foreign Language Annals, 25, 455-464.

[3] Becher, H. J. \& Ravitz, J. L. (2001). Computer use by teachers: are Cuban's predictions correct? Paper presented at the Annual Meeting of the American Educational Research Association. Seattle, WA, March.

[4] Blake, R. (2001). What language professionals need to know about technology. ADFL Bulletin, 32, 3, 93-99.

[5] Blake, R. (2000). Computer Mediated Communication. A Window on L2 Spanish Interlanguage. Language Learning \& Technology, 4(1), 120-136.

[6] Block, J. H., \& Hazelip, K. (1995). Teachers' beliefs and belief systems. In L. W. Anderson (Ed.), International encyclopedia of teaching and teacher education (2nd ed., pp. 25-28). New York: PergammonBorg, S. (2003). Teacher cognition in language teaching: A review of research on what language teachers think, know, believe, and do. Language Teaching, 36, 81-109.

[7] Borg, S. (2003). Teacher cognition in language teaching: A review of research on what language teachers think, know, believe, and do. Language Teaching, 36, 81-109.

[8] Brodskaya, M., \& Thiele, R. (2004). Learning community in a combined ESL computer applications course. Retrieved from http://www.cccone.org/scholars/04-05/Marina_Romy_final_report.pdf. (updated, July 25, 2007 ).

[9] Bubas, G. (2001).Computer mediated communication theories and phenomena: Factors that influence collaboration over the Internet. Zagreb, submitted for the 3ed CARNet Users Conference 1-15.

[10] Chen Y. H. (2005, March). Computer mediated communication: The use of CMC to develop EFL learners' communicative competence. Asian EFL Journal, 7 (1). Retrieve November 09, 2007 from http://www.asian-efljournal.com/march_05_yhc.php.

[11] Cheng, R. (2007). The role of computer-mediated communication in non- native speakers' acquisition of academic literacy. Graduate School Theses and Dissertations. 667. available at: http://scholarcommons.usf.edu/etd/667. 
[12] Chun, D. (1998). Using Computer Assisted Class Discussion to Facilitate the Acquisition Interactive Competence. In J. Swaffar, S. Romano, P. Markley \& K. Arens (eds,). Language Learning Online: Theory and Practice 2 (pp. 57-80). Austin, Tx: Labyrinth Publications.

[13] Conlon, T. \& Simpson, M. (2003). Silicon Valley versus Silicon Glen: the impact of computers upon teaching and learning: a comparative study. British Journal of Educational Technology, 34, 137-150.

[14] Cuban, L., Kirkpatrick, H. \& Peck, C. (2001). High access and low use of technologies in high school classrooms: explaining an apparent paradox. American Educational Research Journal, 38, 813-834.

[15] December, J. (1996). What is Computer-Mediated Communication? Online Retrieved June, 2008, from http://www.december.com/john/study/cmc/what.html.

[16] Drenoyianni, H. \& Selwood,I. (1998). Conceptions or misconceptions? Primary teachers' perceptions and use of computers in the classroom. Education and Information Technologies.3, 87-99.

[17] Eugene, J. (2006). How teachers integrate technology and their beliefs about learning: Is there a connection? Journal of Technology and Teacher Education, 14(3), 581-597.

[18] Frigaard, A. (2002). Does the computer lab improve student performance on vocabulary, grammar, and listening comprehension? ERIC Document Reproduction Service No. ED476749.

[19] Herrings, S. (Eds). (1996). Computer Mediated Communication: Linguistic, social and cross cultural perspectives. Amsterdam: Benjamins.

[20] Hixon, E. (2008). Team-based online course development: A case study of collaboration models. Online Journal of Distance Learning Administration. 11(4). Retrieved from http://www.westga.edu/ distance/ojdla/winter114/hixon114.pdf. (accessed August 4, 2003)

[21] Jonassen, D.H., \& Reeves, T.C. (1996). Learning with Technology: Using Computers as Cognitive Tools. In D.H Jonassen (Ed.), Handbook of research for educational communication and technology (pp. 693-719). New York.: Simon and Schuster.

[22] Kelm, O. (1992). The use of synchronous computer networks in second language instruction. A preliminary report. Foreign Language Annals, 25(5), 441-454.

[23] Kern, R. G. (1995). Learner's and teacher's beliefs about language learning. Foreign Language Annals, 28(1), 71-92.

[24] Lam, Y., \& Lawrence, G. (2002). Teacher-student role redefinition during a computer-based second language project: Are computers catalysts for empowering change? Computer Assisted Language Learning, 15(3), 295-315.

[25] Larsari,V. (2011). Computer mediated communication: The use of CMC to promote EFL learners' communicative competence. Contemporary Online Language Education Journal (COLEJ).1, 41-51.

[26] Leh, A.S.C. (1999). Computer-mediated communication and foreign language learning via electronic mail. Interactive Multimedia Electronic Journal of Computer-Enhanced Learning. Retrieved on 10, Oct, 2004 from http://imej.wfu.edu/articles/1999/2/08/index.asp.

[27] Lightbown, P. M. \& Spada, N. (1999). How languages are learned (Revised Edition) Oxford: Oxford University Press.

[28] Lo, H. (2009). Utilizing Computer-mediated Communication Tools for Problem- based Learning. Educational Technology \& Society, 12 (1), 205-213.

[29] Miner, T. (2004). Using technology to enhance learning: Instructor- or Student-Moderated Discussion Boards: Which are more effective? Retrieved from http://www.cccone.org/scholars/0405/TomMiner_final_report.pdf.

[30] Nguyen, L. (2008). Computer mediated communication and foreign language education: Pedagogical features. International journal of instructional technology and distance learning. 5(12), 23-44.

[31] Nunan, D. (1987). Communicative language teaching. Making it work. ELT Journal 41(2), 136-145.

[32] Pajares, M. F. (1992). Teachers' beliefs and educational research: Cleaning up a messy construct. Review of Educational Research, 62(3), 307-332.

[33] Razak, R. \& Asmawi, A. (2004). The use of dialogue journal through E-mail technology in developing writing interest and skills. Malaysian Online Journal of Instructional Technology (MOJIT). 1(2), 14-23.

[34] Richards, J. C., Gallo, P. B., \& Renandya, W. A. (2001). Exploring Teachers' Beliefs and the Processes of Change. PAC Journal, 1, 1, 41-58.

[35] Schofield, J. W. \& Davidson, A. L. (2003). The impact of internet use on relationships between teachers and students. Mind, Culture, and Activity, 10 (1), 62-79.

[36] Schofield, J. W. (1995). Computers and Classroom Culture. Cambridge: Cambridge University Press.

[37] Staub, F. C. \& Stern, E. (2002). The nature of teachers' pedagogical content beliefs matter for students' achievement gains: quasi-experimental evidence from elementary mathematics, Journal of Educational Psychology, 94, 344-355.

[38] Teo, T., Lee, C. \& Chai, C. (2008). Understanding pre-service teachers' computer attitudes: applying and extending the technology acceptance model. Journal of Computer Assisted Learning. 24, 128-143.

[39] Timucin, M. (2006). Implementing CALL in the EFL context. ELT Journal, 60(3), 262-271.

[40] Tu, C. H. (2002). The Impacts of Text-based CMC on Online Social Presence. The Journal of Interactive Online Learning, $1(2), 1-24$.

[41] Warschauer, M., \& Healey, D. (1998). Computers and language learning: an overview. Language teaching, 31, 57-71.

[42] Williams, M. \& Burden, R. L. (1997). Psychology for language teachers. Cambridge: Cambridge University Press.

[43] Windschitl, M. \& Sahl, K. (2002) Tracing teachers' use of technology in a laptop computer school: the interplay of teacher beliefs, social dynamics, and institutional culture. American Educational Research Journal, 39, 165-205.

[44] Wong, L. (2004). Using technology in a low-advanced ESL class. Retrieved from http://www.cccone.org/scholars/0405/LettyWong_final_report.pdf.

[45] Wozney,L., Venkatesh, V. and Abrami, P. (2006). Implementing Computer technologies: Teachers' Perceptions and Practices. Jl. of Technology and Teacher Education. 14(1), 173-207.

[46] Zaidiyeen, N., Mei, L. \& Fook, F. (2010). Teachers' Attitudes and Levels of Technology Use in Classrooms: The Case of Jordan Schools. International Education Studies. 3(2), 211-218. 
[47] Zhao, Y. (2007). Social studies teachers' perspectives of technology integration. Journal of Technology and Teacher Education, 15 (3), 311-333.

[48] Zheng, H. (2009). A Review of Research on EFL Pre-Service Teachers' Beliefs and Practices. Journal of Cambridge Studies. $4(1), 73-81$

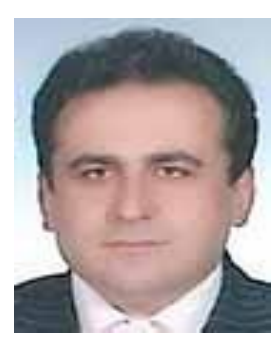

Bahador Sadeghi, an assistant professor of Applied Linguistics holds a doctorate degree in TEFL from the University of Isfahan, Iran. He also holds three MAs in TEFL, English Translation and International Relations from Tehran Islamic Azad University, Isfahan University and Allameh Tabatabaee University respectively.

He has been lecturing different subjects in TEFL, Translation studies, General English and ESP at several universities in Iran for the last nineteen years. He has both published and presented a number of articles in some international journals and conferences.Dr. Sadeghi is the co-author of a book (with Hossein Vahid Dastjerdi, PhD) entitled"An Anthology of Translated Religious \& Literary Texts (With a Glossary of Islamic Terms)" and has translated eight other books from English to Persian.

Dr Sadeghi is also a certified translator to the judiciary power in Iran and he has been, as a simultaneous interpreter, actively involved in many national and international seminars, sport events and tourism projects.

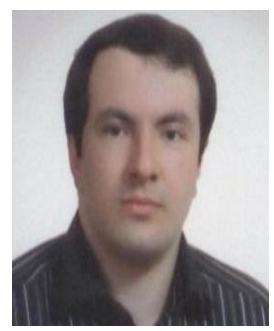

Ramin Rahmany is a Ph.D. holder of teaching English as a foreign language from Tehran University, Iran. Currently, he is an assistant professor in Azad University of Takestan, Iran.

His major interests are language and acquisition, computer assisted language learning, and psycholinguistics. He has taught several courses at university like Language methodology and discourse analysis.

He has published several articles in language learning acquisitions e.g. Acquisition of English Relative Clauses by Persian EFL Learners published by Journal of Language and Linguistic Studies in October 2009.

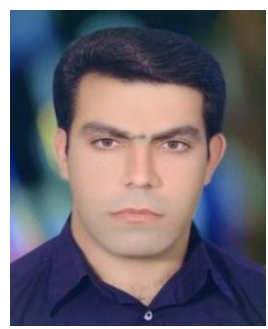

Eskandar Doosti is an MA student in TEFL at Takestan University, Iran. He has been teaching English for more than twenty years in different schools in Sarpole Zohab.

His major interests are language and acquisition, computer assisted language learning, and psycholinguistics. His research interests lie mostly in the realm of EFL. 